\title{
Nijmegen-Bethesda Assay
}

National Cancer Institute

\section{Source}

National Cancer Institute. Niimegen-Bethesda Assay. NCI Thesaurus. Code C159544.

A modification of the Bethesda Assay where the $\mathrm{pH}$ and the protein concentration of the test mixture is further standardized, such that the factor VIII coagulant activity (FVIII:C) in the test mixture is less prone to artifactual deterioration and the test has improved specificity. 